FILOLOGIJA 67, Zagreb 2016.

\title{
Vladimir Horvat
}

UDK 821.163.42'01-05 Belostenec, I. http://doi.org/10.21857/mnlqgcjj4y Izvorni znanstveni članak Primljen 17.IV.2016. Prihvaćen za tisak 27.VI.2016.

Filozofski fakultet Družbe Isusove Hrvatski studiji Sveučilišta u Zagrebu Jordanovac 110, HR-10000 Zagreb vhorvat9@gmail.com

\section{Ivana Klinčić}

Institut za hrvatski jezik i jezikoslovlje Republike Austrije 16, HR-10000 Zagreb ivana.klincic@gmail.com

\section{BELOSTENEC I ENIGMA ZAGUBLJENE ZBIRKE PJESAMA O SV. PAVLU PUSTINJAKU}

\begin{abstract}
U radu se istražuje uloga Belostenca u objavljivanju zagubljene zbirke pjesama o sv. Pavlu Pustinjaku koja se u hrvatskoj književno-jezičnoj povijesti spominje pod naslovom Bogomila. O toj zbirci pjesama govore dva arhivska izvora: 1. Altum Inventarium et Regesta Terrena - Convictus Novi (1722.); 2. Nikola Benger: Catalogus authorum seu scriptorum (oko 1766.). U oba izvora daju se podatci iz kojih se može zaključiti da opisuju isto izdanje. Iako nam danas nije dostupan nijedan primjerak te zbirke, na temelju arhivskoga gradiva moguće je rekonstruirati neke važne okolnosti njezina nastanka.
\end{abstract}

\section{Uvod}

Sv. Pavao Pustinjak (oko 227. - oko 342.) od izuzetne je važnosti za pavline jer je prema tradiciji po njegovu uzoru blaženi Euzebije Ostrogonski formirao grupu redovnika pustinjaka u 13. stoljeću. Crkveno odobrenje pavlinski red dobio je u 14. stoljeću. Sredinom 18. stoljeća pavlinski kroničar Nikola Benger u jednom popisu knjiga naveo je kako je Ivan Belostenec 1665. objavio zbirku pjesama o sv. Pavlu Pustinjaku. Tomu izdanju do danas se zagubio svaki trag. Vjerojatnost da negdje postoji zagubljeno djelo Ivana Belostenca, koje je objavljeno sedam godina prije njego- 
Vladimir Horvat, Ivana Klinčić: Belostenec i enigma zagubljene zbirke pjesama... FILOLOGIJA 67(2016), 49-64

vih propovijedi, pobudilo je našu znanstvenu znatiželju. Jasno nam je bilo odmah da nećemo daleko stići budemo li inzistirali na tom da pronađemo primjerak knjige. Zato smo odlučili iz dostupnoga arhivskoga gradiva izlučiti što više egzaktnih podataka. Budući da su nam bila dostupna samo dva takva izvora, izazov je postao tim veći. Oba arhivska izvora rukopisni su popisi knjiga i oba potvrđuju postojanje izdanja pjesama o sv. Pavlu Pustinjaku čiji naslov počinje riječju Bogomila. To su:

\section{Altum Inventarium et Regesta Terrena - Convictus Novi (1722.)}

2. Nikola Benger: Catalogus authorum seu scriptorum (1766.)

Cilj je našega istraživanja razjasniti o kakvim je knjigama riječ u ta dva popisa te utvrditi opisuju li oba popisa isto izdanje ili dvije različite knjige sličnoga naslova. Budući da se u Bengerovu popisu zbirka pjesama dovodi u vezu s Ivanom Belostencem, u radu se promišlja i njegova moguća uloga ne samo u objavljivanju nego i u sastavljanju te zbirke.

Istraživanje smo proveli filološkom raščlambom zapisa o navedenim primjercima knjige u svakom popisu posebno, a potom smo usporedili dobivene rezultate $\mathrm{u}$ oba zapisa kako bismo utvrdili mogu li se i na koji način dovesti u vezu s Ivanom Belostencem.

\section{Altum Inventarium et Regesta Terrena - Convictus Novi (1722.)}

Altum inventarium et Regesta Terrena - Convictus Novi (HR-HDA-652) bilježnica je u kojoj je popisan ukupni inventar pavlinskoga samostana Novi 1722. godine, o čemu svjedoči i unutarnji naslov: »Inventarium Rerum Monasterii B: V: M: Sub Novi Conscriptum Anno Domini 1722 die ante capitulum Electionum. « ${ }^{1}$ Stranice bilježnice paginirane su naknadno olovkom, počevši od drugoga lista.

Zabilješka koja nas zanima nalazi se na stranici 18, unutar popisa knjiga pod naslovom: »Continuatur Catalogus librorum Monasterii Nouiensis relictorum a Rdo. Patre Adamo Carusi in discessu suo ad Monasterium Lacense. $\ll^{2}$ Iz popisa je vidljivo da je pater Adamo Carusi imao nekoliko knjiga na hrvatskom jeziku, a jedna od njih je:

\footnotetext{
1 »Inventar stvari samostana Blažene Djevice Marije pod imenom Novi godine Gospodnje 1722., dan prije izbornoga kapitula« (preveo Vladimir Horvat).

2 »Nastavlja se katalog knjiga samostana Novi koje su ostale od velečasnoga oca Adama Carusija nakon njegova odlaska u samostan Lacense « (preveo Vladimir Horvat).
} 
Vladimir Horvat, Ivana Klinčić: Belostenec i enigma zagubljene zbirke pjesama...

FILOLOGIJA 67(2016), 49-64

\section{»6. Bogho - Mila 1 Szlatko Popeuka od SHika ${ }^{3}$ S. Paula«.}

U svojoj osobnoj zbirci pater Carusi imao je oko trideset knjiga na različitim jezicima, među njima i više knjiga na hrvatskom. Kod prijelaza u drugi samostan, prema tadašnjem redovničkom običaju, sve je svoje knjige ostavio dotadašnjemu samostanu, u kojem je i sačuvan popis njegovih knjiga.

\section{Bogomila}

Zapis u popisu inventara samostana Novi započinje dvjema riječima koje se $u$ tiskanom obliku mogu prenijeti samo na sljedeći način: »Bogho - Mila«. S obzirom na sastavnice zapisa i pravopisni uzus da se takve složenice pišu sa spojnicom ili crtom te s ili bez razmaka, smatramo da zapis treba čitati kao jednu riječ: bogomila. Po svojem dočetku ta riječ gramatički se može odrediti na dva načina: a) kao nominativ jednine ženskoga roda pridjeva bogomil; b) kao genitiv jednine muškoga roda pridjeva bogomil.

U Belostenčevu rječniku nalazimo potvrdu pridjeva bogomil na više mjesta: »Bogomil. v. Boga bojech« (Gazoph. 2, s. v. Bogomil); »Boga bojech, Bogha bojazliv, [D.] Bogomilli, umilyen. Pius, Religiofus, Devotus, a, um. Pietate præditus, Summâ pictate ornatus, piiffimus, a, um, Deum timens. v. Pobolen« (Gazoph. 2, s. v. Boga bojech). Slijedeći uputu na riječ pobožen, u hrvatsko-latinskom dijelu Belostenčeva rječnika ne dolazimo do novih potvrda za riječ bogomil, 4 ali postoji potvrda na još jednom mjestu: »Narod. [...] 5. pobolen, bogomil, natio pietatis $\int t u d i$ iis dedita, natio pia« (Gazoph. 2, s. v. Narod). U prvom, latinsko-hrvatskom dijelu Belostenčeva rječnika nalazimo dvije potvrde za riječ bogomil i potvrdu za izvedenicu bogomilost: "Addictus, a, um. [...] 2. Devotus. Oblyublyen, Zagovoren, Pobosen. [D.] Zavetan. Bogomil.«(Gazoph. 1, s. v. Addictus); »Pius, a, m. Pobofen, Jna, o. (D.) bogomil, bogoftovni. com. magis piùs. fup. maximè pius, \& piiffimus. Curt.« (Gazoph. 1, s. v. Pius); »Devotio, onis. g.f. 3. Pobofnofzt, 2. pobofno obechanye, alduvanye, bogu prikazanye, pofzvechenye, (D.) Bogolyubfztvo, bogomolfztvo, bogomilofzt. Svet.«(Gazoph. 1, s. v. Devotio).

\footnotetext{
${ }^{3}$ Zapis »SHika« pisarska je greška, vjerojatno umjesto »Sitka«: žitka.

${ }^{4}$ Belostenec $\mathrm{u}$ hrvatsko-latinskom dijelu rječnika kao istoznačnice navodi bogaboječ, bogabojazliv, bogomil, bojazliv i pobožen, no bogomil je povezao samo s riječju bogaboječ. Usp. »Bojazliv, va, vo. [...] 2. v. Bogha bojech.« (Gazoph. 2, s. v. Bojazliv); »Pobòlen. Devotus, pius, religiofus, timoratus, probus, numen adorans, venerans, pietate preditus, devotioni deditus. pobolen chlovek, eubulus. v. Bogabojech. pobolen ofzebuyno k-kojemu Szvetczu, cultu præcipuo venerans quempiam Divum, preculiari veneratione recolens aliquem Sanctum.« (Gazoph. 2, s. v. Pobòfen).
} 
Vladimir Horvat, Ivana Klinčić: Belostenec i enigma zagubljene zbirke pjesama... FILOLOGIJA 67(2016), 49-64

Pridjev bogomil u Belostenčevu rječniku označen je kraticom D. (dalmatice), što znači da pripada južnomu hrvatskomu jezičnomu korpusu. Tomu u prilog ide i to što je ne nalazimo kod Habdelića i Jambrešića, kod kojih su joj suznačni pridjevi alduvan, ${ }^{5}$ bogaboječi, ${ }^{6}$ bogoštovni, ${ }^{7}$ duhovni, ${ }^{8}$ pobožen, ${ }^{9}$ posvečen, ${ }^{10}$ redovni, ${ }^{11}$ zagovorjen. ${ }^{12}$ Pridjev bogomil, i njegove izvedenice, potvrđen je $u$ Mikaljinu rječniku u nizu natuknica povezanih $s$ riječju Bog, u istom značenju koje navodi Belostenec: »bogo milli, a, o [...] Ne bogomilli [...] Veoma bogo milli [...] Bogomillo [...] Nebogomillo [...] bogomillóft [...] Nebogomillóft [...] bogogljubno. Vidi bogomillo. bogogliuban. Vidi bogomilli« (Mikalja 1649: 22). Potvrda je to da se Belostenec, uvodeći tu riječ u svoj rječnik, poslužio Mikaljinim rječnikom.

Osim pridjeva bogomil, postoje i potvrde muškog osobnog imena Bogomil. To ime danas se povezuje s istočnim južnoslavenskim jezičnim područjem (Bugarska, Makedonija), a u zapadnoslavenskim jezicima inačice su mu Bogumit (Poljska) i Bohumil (Češka i Slovačka). Akademijin rječnik određuje ga kao »ime muško, prije našega vremena « pozivajući se na izvor srpskoga jezika (AR 1: s. v. 2. Bogomil). Pretpostavku da bi moglo postojati žensko osobno ime Bogomila nismo potvrdili ni u izvorima ni u Akademijinu rječniku.

Ako zapis Bogomila u novljanskom popisu knjiga tumačimo kao nominativ jednine ženskoga roda pridjeva bogomil, u nastavku teksta uočavamo zapis »Popeuka «kao imenicu na koju bi se mogao odnositi taj pridjev. Tada bismo početak zapisa mogli tumačiti na sljedeći način: Bogomila $i$ slatka popevka - uzimajući u obzir značenja riječi bogomil kako tumači Belostenec u svom rječniku. No, u takvom tumačenju imali bismo dva sporna mjesta: 1 . zapis koji je nedvojbeno brojka 1 tumačili bismo kao veznik $i ; 2$. dočetak $\mathrm{u}$ »Szlatko« tumačili bismo kao slovnu pogrešku. Budući da grafija cijeloga zapisa odgovara sjeverozapadnoj hrvatskoj slovopisnoj tradiciji, očekivani zapis veznika $i$ bio bi: $y$. Da bismo Bogomila odredili kao nominativ jednine ženskoga roda, morali bismo prilagoditi tumačenje drugih dijelova zapisa, koji su zapravo nesporni, pa smo tu opciju odbacili.

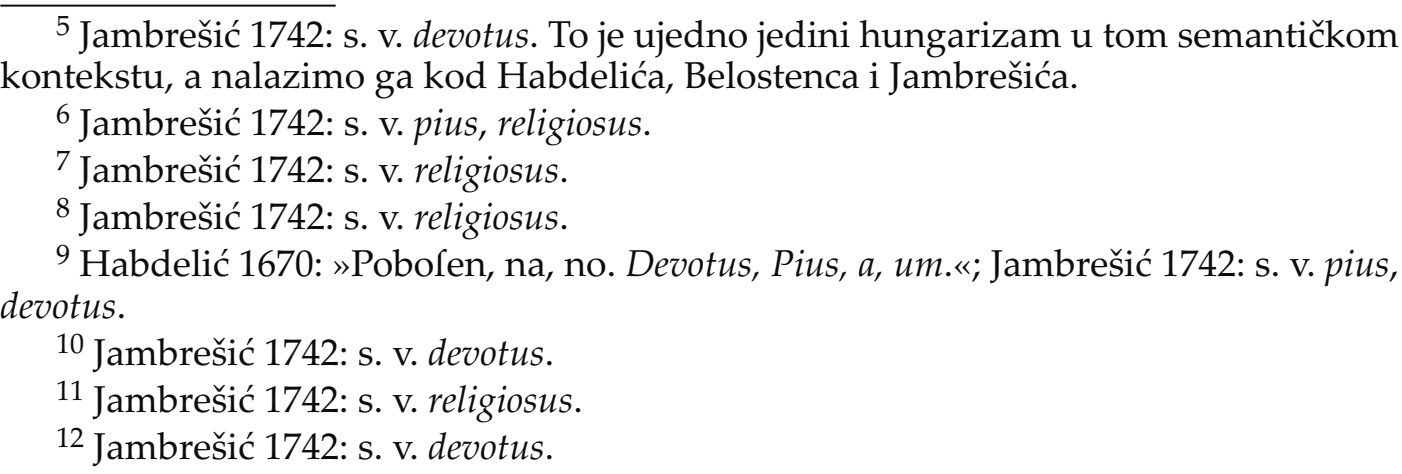


Vladimir Horvat, Ivana Klinčić: Belostenec i enigma zagubljene zbirke pjesama... FILOLOGIJA 67(2016), 49-64

Pretpostavimo li da je Bogomila naslov zbirke dobiven supstantivizacijom ženskoga roda pridjeva bogomil, dobivamo mogući naslov s podnaslovom: Bogomila : 1 (jedna) slatkopopevka od žitka s. Pavla. To bi trebalo uzeti u obzir kao jedno od mogućih tumačenja, imajući pritom na umu i to da Bogomila nije potvrđeno osobno ime $\mathrm{u}$ tom razdoblju.

Ako potvrdu Bogomila tumačimo kao genitiv jednine muškoga roda, zapažamo da je riječ o imeničkoj sklonidbi te da nema imenice na koju bi se mogao odnositi taj pridjev. Takvo tumačenje dovodi nas do sljedećega čitanja: Bogomila 1 (jedna) slatkopopevka. U tom slučaju moguća su tri tumačenja prve riječi zapisa:

1. pridjev u imeničkoj službi: bogomil 'pobožan';

2. poimeničeni pridjev: bogomil 'zavjetovani (redovnik)';

3. osobno ime: Bogomil.

S obzirom na to da je riječ o popijevci posvećenoj utemeljitelju pavlinskoga reda, koji je ujedno pavlinima uzor redovničkoga života, smatramo drugo tumačenje najvjerodostojnijim. Ne treba isključiti ni mogućnost namjerne višeznačnosti naslova, kao ni mogućnost da je osoba imenom Bogomil autor navedene popijevke.

Slatkopopevka

U 17. i 18. stoljeću još je uobičajen obrazac da se granica riječi određuje naglasnim cjelinama, posebice kad je riječ o složenicama. Kako u sintaktičkoj okolini nema glagola zbog kojega bi se moglo pomišljati na to da je »Szlatko« prilog, zapis »Szlatko Popeuka « treba čitati slatkopopevka.

U Habdelićevu, Belostenčevu i Jambrešićevu rječniku nema potvrde za riječ slatkopopevka, no objašnjenja povezana s latinskom riječi melodia upućuju nas na njezino moguće značenje: »Melodia, ae, f. melos. Szladko y vugodno popevanye (Gazoph. 1: s. v. Melodia); »Popevànye. [...] vugodno, y szladko popevanye, melodia (Gazoph. 2: s. v. Popevànye); »*Mĕlōdīa juxta accentum, re ipsa Melodĭa, ae, f. Martian. Capella. Szladka y draga popevka, vugodno fzkup fzlaganye gláfza. Ein lieblicher Gefang, angenehme Zufamenftimmung. [...] Melos, Concentio, Cantilena« (Jambrešić 1742: s. v. Mělōì̄a).

Iz toga je vidljivo da je slatkopopevka isto što i latinski melodia ${ }^{13}$, što znači da je riječ o popijevki, tekstu namijenjenom pjevanju, a ne o pjesmi u širem smislu, tj. samim stihovima. Iz toga slijedi mogućnost da je u navedenom izdanju mogao biti i notni zapis.

${ }^{13}$ Usp. »melodia, ae f Mart. Cap. (modi, ili modŭli musĭci) melodija; skladan niz zvukova; vrsta popijevke« (Marević 2000: s. v. melodia). 
Vladimir Horvat, Ivana Klinčić: Belostenec i enigma zagubljene zbirke pjesama... FILOLOGIJA 67(2016), 49-64

U semantičkom okruženju koje se odnosi na pjevanje nalazimo još potvrde za imenice sladkopevec i sladkopojac te pridjeve sladkopevni, sladkoglasen i sladkoglas: »Dulcifonus, a, um. g. o. p. c. Szladko glafzen, fzna, no. fzladko glafz, fza, fzo. Sidon« (Gazoph. 1: s. v. Dulcifonus); »Melodus, di. melodes, is. m. p. p. Szladko pevec, vugodno pevecz. Sid.« (Gazoph. 1: s. v. Melodus); »Melodus, a, m. p. p. Szladko peoni. idem « (Gazoph. 1, s. v. Melodus); »Dulcĭsŏnus, a, um, Sidon. Szladko-glafz. Einer süslischer, lieblicher Stimm « (Jambrešić 1742: s. v. Dulcŭsŏnus); »*Mĕlōdes, is, m. Sidon. Szladkopevecz, fzladko-pojacz, drago-poja. Ein lieblicher Singer. ékefen éneklo. Vid. Muficus, Dulciloguus, Dulcifonus, Cantator, Concentor (Jambrešić 1742: s. v. Mĕlōdes); »Mĕlōdus, a, um. Aufon. Szladko-drago-glas. Lieblich thönend. [...] Vid. Dulcifonus, Melicus« (Jambrešić 1742: s. v. Mĕlōdus).

Iz naslova popisa knjiga koje su ostale nakon odlaska patra Adama Carusija jasno je da je riječ o tiskanoj knjizi, iako nije navedeno mjesto i godina izdanja, jer popisivač ni za druge knjige nije navodio te podatke. Iz popisa proizlazi da je 1722. u pavlinskom samostanu Novi postojao primjerak te knjige. Budući da su knjige s crkvenim popijevkama bile predmeti kontinuiranoga korištenja, te stoga podložne trošenju, upitno je u kakvom je stanju već tada bio taj primjerak. To se moramo zapitati naročito ako spomenuti zapis dovedemo u vezu s četrdesetak godina mlađim Bengorovim zapisom, u kojem on tvrdi da knjiga sličnoga naslova sadržava jednu pjesmu o životu sv. Pavla Pustinjaka i dvanaest himni istomu svetcu. Ako je riječ o istom izdanju, primjerak iz samostana Novi možda nije bio cjelovit, jer spominje samo prvu popijevku.

\section{Nikola Benger: Catalogus authorum seu scriptorum (1766.)}

Pavlin Nikola Benger (1695. - 1766.) sastavio je popis pavlinskih knjiga pod naslovom Catalogus Authorum Seu Scriptorum Ex Religiosis ordinis S. Pauli primi Eremitae, Qui aliqua Doctrina aut pietatis monumenta Scriptis ediderunt. Collectus per P. Nic. Ben. eiusdem Ords (HR-MP-127). ${ }^{14}$ Benger u svo-

$14 »$ Katalog autora ili pisaca iz reda sv. Pavla Prvog Pustinjaka koji su objavili neke spise o znanosti ili pobožnosti. Skupio pater Nikola Benger iz istog reda« (prijevod Vladimir Horvat). Najmlađa datacija do Appendixa je 1762. godina (12r). Kad je zapisivač unosio podatke o Gašparotiju, nije unio podatke o druga dva dijela njegova Cveta sveteh, koji su objavljeni 1760. i 1761. godine, ali je upisao »\# vide additam « (HRMP-127: 7r). To bi mogla biti potvrda toga da je zapisivač unosio podatke samo za one knjige koje je imao u ruci, ali je znao za Gašparotijeva druga dva izdanja te da će to trebati nadopuniti. Zapisivač nije upisao ni datum Gašparotijeve smrti 6. ožujka 1762. godine. Svi ti podatci konačno se nalaze tek u Appendixu. Najmlađa datacija (i ujedno posljednja u popisu knjiga) je 1764. u Appendixu (HR-MP-127: 15v). Dakle, zapisivač je s upisom kataloga autora započeo 1762. (i to prije 6. ožujka), a završio ga je 1764. 
Vladimir Horvat, Ivana Klinčić: Belostenec i enigma zagubljene zbirke pjesama...

FILOLOGIJA 67(2016), 49-64

jem popisu donosi najprije autore, a zatim navodi njihove knjige. Vidljiva je težnja da se upisuju samo ona djela koja su popisivaču u tom trenutku bila dostupna. Djela povezana s Belostencem navode se na sljedeći način:

»P. Belosztenecz Ioannes, natione Croatus, Prior aliquando Lepo-glaven[sis] ad a. 1651. postea Provincialis Istriae, et iterum deinde reversus ad nativam Provinciam, Obiit Lepoglavae. 1675.

Conscripsit Gazophylacium linguae Illyricae, sive Dictionarium Illyrico-latinum, \& Latino-Illyricum, impressum Zagrabiae. 1740.

Item Conciones decem de SS. Corpore Christi, idiom[ate] Croatico, I: tacito suo nomine editas :I de quibus refert Album Lepoglavense, ad a. 1672.

Item Varia poëmata de S. P. Paulo primo Eremita, idiomate Croat[ico] sub titulo : Boghomila, typis Graecensibus edita. 1665. Inter quae prima Melodia, concinnata 113 versibus quadrimetris, iuxta numerum annorum Vitae S. P. Pauli eiusdem pangit gloriosum Vitae cursum. Alii sunt 12 hymni de eodem Divo. ${ }^{15}$ (HR-MP-127: 3v)

Benger je upravo zbirci pjesama posvetio najviše prostora i o njoj je dao najviše podataka: Zbirka se sastoji od različitih pjesama. Napisana je idiomate Croatico, što tada znači hrvatskim kajkavskim književnim jezikom i sjeverozapadnim hrvatskim slovopisom. Naslovljena je Boghomila te tiskana u Grazu 1665. godine. Prvi napjev (melodia) ima 113 stihova, prema broju godina života sv. Pavla Pustinjaka. Ostatak zbirke čini 12 himana u slavu istoga svetca.

Vezu Belostenca sa zbirkom pjesama Benger opisuje: »Item Varia poëmata [...] typis Graecensibus edita.« Pitamo se na kakvu Belostenčevu ulogu u objavljivanju zbirke to ukazuje. Je li je samo objavio ili je možda i napisao. U prethodne dvije natuknice Benger piše za Gazophylacium da ga je Belostenec napisao (conscripsit), a za propovijedi naznačava tacito suo nomine editas, tj. prešutjevši svoje (autorsko) ime objavio je. U Belostenčevu i Jambrešićevu rječniku nalazimo objašnjenje: »edere librum, van dati, ali Itampati dati knyigu « (Gazoph. 1: s. v. Edo); »Edere libros. Knige Stampati, pritiszkati: Knige van davati. Die Bücher trucken: oder heraus geben « (Jambrešić 1942: s. v. edo). Iz istoga korijena ima više latinskih riječi koje se odnose na radnju izdavanja knjiga: »librorum editio, van davanye, ali ftampanye knyig" (Gazoph. 1: s. v. Editio); „Editor, oris. g. m. 3. p. c. Ván

godine. Katalog autora samo je prvo od ukupno šest poglavlja u Bengerovoj bilježnici, ali se cijela bilježnica tehnički vodi pod naslovom tog prvog popisa. Nakon Bengerove smrti još ima nekoliko pojedinačnih upisa, a posljednja datacija je 1779. godina (HR-MP-127: 20v). Mi smo rukopis kao cjelinu datirali u 1766. godinu, smatrajući da se Bengerovom smrću taj popis knjiga, provincijala i drugih podataka može smatrati završenim. 
Vladimir Horvat, Ivana Klinčić: Belostenec i enigma zagubljene zbirke pjesama... FILOLOGIJA 67(2016), 49-64

daynik, ván dajëcz. koi ván daje, ali knyigu ftampati chini. it. napervo dona Javecz fta god. Lucan« (Gazoph. 1: s. v. Editor); „Editio librorum, Quin. Stampanye knig y van davanye. Das Trucken oder herausgeben der Bücher « (Jambrešić 1942: s. v. Editio); »Editor librorum« (Jambrešić 1942: s. v. Editor). Iz toga slijedi da Belostenca ne možemo smatrati autorom te zbirke pjesama jer je nesporna razlika u značenju latinskih riječi conscribere (napisati) i edere librum (objaviti knjigu). Osim toga, Benger je prvo nabrojio dvije autorske Belostenčeve knjige, a zatim zbirku pjesama, koju je Belostenec samo objavio, jer bi inače kronološki trebala biti navedena prije propovijedi.

O zbirci pjesama koju je Benger povezao s Belostencem kasniji su istraživači donosili iznenađujuće tvrdnje i zaključke, pa su zbog toga i tako siromašni podatci o zagubljenom izdanju postali još manje jasni.

Stotinu godina nakon Bengerove bilješke, Ivan Kukuljević Sakcinaki navodi da je Belostenec autor »Šest pesmih od sv. Pavla pervoga pušćenika. U Gradcu 1665. (Kukuljević Sakcinski 1860: 20). ${ }^{16}$ Budući da Kukuljević misli da zbirka ima šest (a ne 13) pjesama i ne navodi naslov zbirke, sigurni smo da mu Bengerov popis nije bio dostupan. $S$ Bengerovim popisom sukladni su sljedeći podatci: 1. zbirka pjesama je o sv. Pavlu Pustinjaku; 2. zbirka je tiskana u Grazu 1665.; 3. povezuje se s Belostencem. Različiti su podatci: 1 . ne navodi se naslov zbirke; 2 . različit je broj pjesama; 3 . ne navode se ostali detalji iz Bengerova popisa. Kukuljević nije u rukama imao ni samu zbirku jer bi inače naveo više podataka: broj stranica, tiskaru i format knjige. Zato valja pretpostaviti da je imao neki drugi izvor podataka.

Osam godina kasnije Kukuljević se opet osvrnuo na Belostenčevo navodno pjesničko stvaralaštvo: »Belostenec bijaše osim toga veoma učen bogoslovac, propoviednik i pjesnik hrvatski, te je g. 1665 izdao u Gradcu pod naslovom: 'Bogomila' svoje pobožne piesme, na čast sv. Pavla prvoga pušćenika, od kojih piesamah imade prva 113 verasah. Isto tako uvrstio je i u svoj riečnik mnogo svojih verasah, dapače i dovršio ga s pjesmom « (Kukuljević Sakcinski 1868: 184). Kukuljević je prijašnjim podatcima pridodao naslov i broj stihova pa možemo pretpostaviti da je tada konačno mogao

\footnotetext{
${ }^{16}$ Cjeloviti Kukuljevićev popis Belostenčevih djela:

»178 Bělostěnec Ivan, Pavlin. Gazophylacium, seu latino-illyricorum onomatum aerarium, plurimis authorum in hoc opere adductorum sententiis idiomate illyrico delicatis illustratum, et peculiariter Illyriorum commodo apertum. Zagrabiae typis J. B. Weitz 1740 in 4. pag. 1288. - Tomus II. Gazophylacium Illirico-latin. in 4. pag. 650.

179 “ Šest pesmih od sv. Pavla pervoga pušćenika. U Gradcu 1665.

180 “ (Horanyi kaže, da je još izdao): Predike o sv. tielu Isusovom na hrvatskom jeziku.« (Kukuljević Sakcinski 1860: 20).
} 
biti upoznat s Bengerovim popisom, no nejasno je zašto onda nije ispravio navod o broju pjesama.

Đuro Šurmin služio se očito Kukuljevićevom bibliografijom kad je napisao: »Od Belostenca ima i Šest pesmih od sv. Pavla prvoga pušćenika« (Šurmin 1898: 138). Kasnija Kukuljevićeva objava na tu temu očito mu nije bila poznata. Branko Vodnik koristio je oba Kukuljevićeva teksta: »Belostenec izdao je 'Bogumilu šest pesni na čast sv. Pavla' (Grac, 1665.), gdje u prvoj pjesmi crta život osnivača svoga reda, a u ostalima slavi njegove kreposti« (Vodnik 1913: 274), ali je krivo prepisao naslov zbirke. Ni Šurminu ni Vodniku očito nije bio dostupan Bengerov katalog.

László Hadrovics prvi je objavio Bengerov popis Belostenčevih djela kao bilješku uz komentar krnjega primjerka Belostenčevih propovijedi iz budimpeštanske sveučilišne knjižnice:

»Kako je štamparski arak sa str. 1 obilježen slovom B a ne slovom A, znači, da na početku knjige manjka arak A, koji je pored naslovnoga lista sadržavao valjada još samo posvetu knjige, jer je >Bogomila<, zbirka njegovih pjesama na čast sv. Pavla, bila štampana god. 1665.« (Hadrovics 1939: 42).

Na prvi pogled zbunjuje Hadrovicsevo povezivanje nedostatka arka A u zbirci propovijedi sa zbirkom pjesama, no čini se da je Hadrovics pomišljao na to da su pjesme mogle biti uvodni tekst propovijedima.

Josip Vončina 1997. prigovorio je Vodniku kako je u povijest hrvatske književnosti uveo neprovjerenu tvrdnju »da se zbirka Belostenčevih pjesama zvala Bogumila (Vončina 1997: 327). Vončina se u svojim dotadašnjim radovima o Belostencu nije posebno zainteresirao za tu zbirku pjesama pa nije uočio Hadrovicsevu bilješku u kojoj citira Bengerov popis (Hadrovics 1939: 42), iz koje je vidljivo da je Vodnik imao barem donekle ispravne podatke. Taj propust Vončina je ispravio već sljedeće godine prigodom objave drugoga (luksuzno opremljenog) pretiska Belostenčeva rječnika.

Drugomu pretisku Gazophylaciuma (1998.) pridodana je knjižica s dvije studije, Josipa Vončine i Josipa Bratulića, te prijevodi latinskih tekstova. Josip Vončina u svojem tekstu Promicatelj hrvatskoga jezičnog jedinstva preuzeo je podatke o navodnoj Belostenčevoj zbirci pjesama iz Hadrovicseva predgovora Belostenčevim propovijedima, a posebno se osvrnuo na dio Bengerova zapisa typis graecensibus: »Belostenec je (prema Bengeru) 1665. izdao zbirku Boghomila, koja je sadržala trinaest pjesama o sv. Pavlu. Bila je tiskana hrvatskim jezikom i 'typis graecensibus', tj. ćirilicom. Ta tvrdnja nije nevjerojatna, jer je Belostenec pokazao da ćirilicu poznaje: u rječniku ustvrdivši kako se suglasnik z bilježio 'po fztaro horvatfzko 3' « (Vončina 1998: 7). Površno čitanje typis graecensibus kao "grčkim slovima" na- 
Vladimir Horvat, Ivana Klinčić: Belostenec i enigma zagubljene zbirke pjesama... FILOLOGIJA 67(2016), 49-64

velo je inače uvijek preciznoga Josipa Vončinu na krivi trag, pa je podatak da je knjiga tiskana u Grazu protumačio kao da je pisana ćiriličkim slovima. Da je Vončina imao u rukama Bengerov rukopis, sigurno bi uočio da Benger u bibliografskim podatcima daje i mjesto tiskanja, primjerice: »impressum typis Clari Montis Scestokoviensis « (HR-MP-127: 2r); »quod editum est typisViennensibus « (HR-MP-127: 2r); »editum typis Tyrnaviensibus « (HR-MP-127: 3v); »edidit typis Posoniensibus « (HR-MP-127: 6r); »typis Cracoviensibus impressam « (HR-MP-127: 7r); »edidit typis Zagrabien.« (HR-MP-127: 9v); »impressum typis Labacensibus « (HR-MP-127: 12r); »typis Constantiensibus evulgatum « (HR-MP-127: 14r); »impressus est typis Cracoviensibus (HR-MP-127: 14r). Benger navodi i obimno djelo Hilariona Gašparotija Cvet sveteh, za koje znamo da je tiskano u Grazu i Beču: 1. dio: »Impressa Graecij. 1752.« (HR-MP-127: 7r): 2. dio: »Impressa Graecij. 1756.« (HR-MP-127: 7r); 3. dio: »typis Viennen.« (HR-MP-127: 15r); 4. dio: »typis Viennensibus A. D. 1761.« (HR-MP-127: 15r). I bez Bengerova rukopisa, objašnjenje spornoga mjesta može se pronaći u kajkavskim rječnicima: »Gradecz Nemski. Græcium, ij, n. Styrorum. « (Habdelić 1670: s. v. Gradecz Nemski); »Gràdëcz nem[ki. [D.] nemachki gradacz, ali gracz ú Stajeru. Græcium Stiriæ, favoria.« (Gazoph. 2: s. v. Gràdëcz nemfki); "Græcium, ii, n. Geog. Gradecz, lépi y pervi varaß Jtajerfzke Derfave. Grätz, e. Haupt-Stadt in Steyer-Marck. (Jambrešić 1942: s. v. Græcĭum); »Stīrŭa, æ, f. Geogr. Stajerzka zemlya. Steyer, die Landfchafft Steyermarck. Staer-orfzág. Parsantiqui Norici \& Pannoniæ fuperioris. A populo Illyrico hodiedum magna fui parte colitur. Caput ejus Græcium. (Jambrešić 1942: s. v. Stìrrăa).

\section{Belostenec i pavlinska glazbena baština u Hrvatskoj}

Važnost pjevanja i glazbe kod pavlina opisuje se i u konstitucijama Reda, gdje su propisane i obveze i zaduženja vezana uz liturgijsko pjevanje (Barlè 1916-1917: 10/20). Hrvatsku pavlinsku glazbenu baštinu načelno čine zapisi crkvenih napjeva i sačuvani primjerci orgulja. Arhivski izvori pokazuju da su do druge polovice 18. stoljeća skoro svi pavlinski samostani imali orgulje, a orgulje koje su 1649. sagrađene u lepoglavskom samostanu danas se ubrajaju u pet najdragocjenijih glazbala te vrste u Hrvatskoj (Meder 1989: 335).

Lepoglavski samostan imao je i skriptorij te je za prijepis koralnih tekstova uvijek bio zadužen barem jedan od redovnika, kontinuirano je djelovao do ukinuća reda 1786. godine (Šaban 1989). Sastavljači crkvenih pjesmarica često su bili obrazovani svećenici ali bez glazbene stručnosti, koji su se pritom služili predlošcima (Kos 1991: 340). Primjerice, Ivan Beloste- 
nec povezuje se s nastankom rukopisne pavlinske zbirke liturgijskih tekstova nazvane Pavlinski zbornik, datiranoga u 1644. godinu, koji sadržava liturgijske tekstove na latinskom i hrvatskom kajkavskom jeziku namijenjene bogoslužju, na dvjestotinjak gotovo do kraja paginiranih folija. Od 90. do 170. folije zbornik sadržava i zbirku crkvenih pjesama s notnim zapisima, koju ćemo u radu dalje imenovati Pavlinska pjesmarica.

Pavlinska pjesmarica "prva je dosad poznata rukopisna zbirka jednoglasnih crkvenih napjeva nastala u Hrvatskoj i za upotrebu u Hrvatskoj« (Kos 1991: 338). U njoj su crkvene popijevke i duhovne narodne popijevke raspoređene prema razdobljima crkvene godine, a većina napjeva pripada međunarodnoj tradiciji (Kos 1991: 339-341). Dio istraživača Pavlinskoga zbornika iznio je mogućnost da je njegov "autor", sastavljač ili redaktor Ivan Belostenec (Šojat 1991). Pisanje tog djela svakako pada u razdoblje Belostenčeve zrele produktivne dobi i odgovornih službi, pa je stoga mogao na neki način sudjelovati u izradi Pavlinskoga zbornika. Danas možemo nagađati je li on samo znao na čemu se radi, ili je sudjelovao u planiranju, sastavljanju i redigiranju Pavlinskog zbornika. Pavlinski red je među redovnicima imao dovoljno sposobnih članova koji su mogli provesti odluku o pisanju takvoga zbornika nakon što se utvrdi potreba za takvim djelom. ${ }^{17}$

Analiza leksičkoga fonda u Belostenčevu rječniku pokazala je široku razgranatost glazbenoga nazivlja u vezi s 19 glazbala (Tuksar 1983). U praktičnom Belostenčevu pastoralnom radu, a prema tomu i u možebitnom uređivanju pjesmarica, bitno je moglo biti samo poznavanje orgulja i srodnih glazbala prihvatljivih za liturgiju u pavlinskim samostanima te znanja u vezi s pjevanjem i zapisivanjem melodija.

Pjesmarice su zbog stalne uporabe bile podložne ubrzanomu trošenju. Tekstove za svakodnevnu uporabu bilo je isplativije prepisivati. Tiskanje knjige u 17. stoljeću bilo je skupa investicija pa je onaj tko je ulagao sredstva u takav pothvat morao imati jasnu predodžbu o svrsi tiskanja istoga teksta u nekoliko stotina primjeraka i moralo je biti jasno tko će te njegove knjige kupovati. Osim financijskih sredstava, tiskanju knjige prethodili su i zahtjevni organizacijski i crkveno-pravni postupci. Kad je riječ o crkvenim redovima, te su okolnosti bile još složenije jer je tekst koji se želio tiskati morao proći provjere unutar reda, a potom dobiti i odobrenje nadležnoga biskupskoga ordinarijata.

Mišljenja smo da bi se Belostenec, kao već ugledan redovnik, mogao

\footnotetext{
${ }^{17}$ O okolnostima i razlozima sastavljanja Pavlinskog zbornika v. Zagorac 1991.
} 
Vladimir Horvat, Ivana Klinčić: Belostenec i enigma zagubljene zbirke pjesama... FILOLOGIJA 67(2016), 49-64

za potrebe Reda upustiti u sastavljanje jedne specijalizirane pjesmarice, usmjerene na tada već postojeće napjeve o sv. Pavlu Pustinjaku, kao što je izdanje Bogomila iz 1665. godine. Ukoliko je postojao dovoljan broj takvih himničkih popijevaka, može se pretpostaviti da je pavlinski red želio te popijevke na slavu svoga svetačkoga uzora i objaviti ili da je postojao donator koji je u tom trenutku želio pomoći tiskanje takve jedne manje zbirke. Iz dostupnih podataka u Bengerovoj bilješci vidljivo je da Belostenec nije autor tog izdanja, nego da ga je vjerojatno samo priredio za objavljivanje.

\section{Zaključak}

U zaključku moramo dati odgovor o odnosu Belostenca i zagubljene zbirke pjesama o sv. Pavlu Pustinjaku. Budući da zagubljenu zbirku nismo pronašli, enigmu smo riješili na temelju tekstova do kojih smo došli: 1 . katalog knjiga u pavlinskom samostanu Novi iz 1722.; 2. Bengerov katalog pavlinskih autora knjiga napisan oko 1766. godine.

Knjiga koja je navedena u inventaru samostana Novi i knjiga koja se opisuje u Bengerovu popisu imaju tri zajedničke sastavnice: objema naslov počinje s Bogomila, u obje se pjesma o životu sv. Pavla Pustinjaka opisuje kao popijevka istoznačnicama slatkopopevka i melodia te su obje napisane hrvatskim jezikom i sjeverozapadnom hrvatskom grafijom. Na temelju tih podataka zaključujemo da je riječ o istom izdanju.

Zbirka je u hrvatsku književno-jezičnu povijest ušla pod nazivom Bogomila. Budući da je u novljanskom popisu zapisan cjelovit naslov (iako bez ostalih podataka), filološkom raščlambom njegove gramatičke strukture došli smo do četiri moguća i prihvatljiva tumačenja zapisa »Bogho - Mila 1 Szlatko Popeuka od SHika S. Paula«:

1. 'Bogomila : jedna popijevka o životu sv. Pavla' - pritom je prva riječ naslov knjige nastao supstantivizacijom nominativa jednine ženskoga roda pridjeva bogomil;

2. 'Pobožnoga jedna popijevka o životu sv. Pavla' - u tom slučaju Bogomila je pridjev u imeničkoj službi u genitivu jednine muškoga roda;

3. 'Zavjetovanoga (redovnika) jedna popijevka o životu sv. Pavla' $-u$ tom slučaju Bogomila je poimeničen (supstantivizirani) pridjev u genitivu jednine muškoga roda;

4. 'Bogomila jedna popijevka o životu sv. Pavla' - u tom slučaju Bogomila je osobno ime u genitivu jednine. 
Vladimir Horvat, Ivana Klinčić: Belostenec i enigma zagubljene zbirke pjesama...

FILOLOGIJA 67(2016), 49-64

S obzirom na povijesni kontekst pavlinskoga reda, mišljenja smo da je treće tumačenje najvjerodostojnije.

Budući da su se pavlini bavili liturgijskim pjevanjem, plod njihova rada je rukopisni Pavlinski zbornik dio kojega je i Pavlinska pjesmarica. Očekivali smo da je zagubljena zbirka uklopljena u Pavlinski zbornik, no u njemu nema pjesama o sv. Pavlu Pustinjaku. Smatramo vjerojatnim da su pavlini skupili popijevke o sv. Pavlu Pustinjaku te ih odlučili objaviti kao knjižicu na čast svojemu svetcu. Za taj je posao određen iskusan i ugledan pater Belostenec, koji je zbirku priredio i objavio, te je stoga Nikola Benger zapisao: »Item Varia poëmata [...] typis Graecensibus edita.«

Iz dostupne građe vidljivo je da je 1722. postojao primjerak te knjige $\mathrm{u}$ pavlinskom samostanu Novi, no nejasno je u kakvu je bio stanju jer spominje samo jednu popijevku, i to onu o životu sv. Pavla Pustinjaka, a druge pjesme prešućuje. Novljanski popis o svim knjigama daje samo šture podatke, pa se ne može utvrditi je li taj primjerak bio krnji ili je zapisivač upisao samo kratku bilješku onoga što je na knjizi bilo najupečatljivije. Prije 1766. u lepoglavskom samostanu morao je također postojati primjerak te zbirke pjesama jer ju je zabilježio Nikola Benger te, uz druge podatke, ustvrdio da sadržava jednu popijevku o životu sv. Pavla Pustinjaka i 12 himni istomu svetcu.

Danas nam nije dostupan ni jedan primjerak pavlinske zbirke popijevaka o sv. Pavlu Pustinjaku tiskane u Grazu 1665. godine. Preostaje nam nada da će se jednog dana u nekoj biblioteci ili arhivu ipak pronaći. Mi smo ipak na temelju dostupne sekundarne građe došli do mnogih novih spoznaja o tom zagubljenom i možda zauvijek nestalom izdanju. Razjasnili smo nejasnoće i uklonili zablude nastale površnim čitanjem dostupnih izvora te, nadamo se, odškrinuli vrata pronalasku i/ili prepoznavanju opisane zbirke popijevaka u globalnom mnoštvu digitaliziranih podataka koje velike svjetske biblioteke i arhivi neprestano čine dostupnima na Internetu. 
Vladimir Horvat, Ivana Klinčić: Belostenec i enigma zagubljene zbirke pjesama... FILOLOGIJA 67(2016), 49-64

\section{Literatura}

AR 1-23 = Rječnik hrvatskoga ili srpskoga jezika. I-XXIII. Zagreb : Jugoslavenska akademija znanosti i umjetnosti, 1880. - 1975.

Barlè, Janko. 1913. Lepoglavski Pavlini i crkvena glazba. Sv. Cecilija : Smotra za crkvenu glazbu sa glazbenim prilogom: Glasilo "Cecilijinog društva" u Zagrebu. 3 (1913), 37-38.

Barlè, Janko. 1916. - 1917. Pavlinska pjesmarica iz god. 1644. Sv. Cecilija : Smotra za crkvenu glazbu sa glazbenim prilogom: Glasilo "Cecilijinog društva" u Zagrebu. 10-11 (2016-2017), 10 / 18-20, 49-51, 77-79, 108$110,150-153,177-180 ; 11$ / 8-10, 45-49, 88-90, 122-126, 158-160, $191-195$.

Gazoph. $1-2$ = Admodum reverendi patris Joannis Bèllosztènëcz, e sacra d. Pauli primi eremitae religione Gazophylacium seu latino-illyricorum onomatum aerarium, selectioribus synonimis, phraseologiis, verborum constructionibus metaphoris, adagiis, abundantissime locupletatum, item plurimis authorum in hoc opere adductorum sententiis idiomate Illyrico delicatis illustratum. Zagreb : Typis Joannis Baptistae Weitz, Inclyti Regni Croatiae Typographi, 1740.

Hadrovics, László. 1939. Deset propovijedi o Euharistiji pavlina o. Ivana Belostenca. Za štampu priredio László Hadrovics. Građa za povijest književnosti hrvatske, 14 (1939), $41-44$. Zagreb : Jugoslavenska akademija znanosti i umjetnosti - Nadbiskupska tiskara.

Jambrešić, Andrija. 1742. Lexicon latinum interpretatione Illyrica, Germanica, et Hungarica locuples, in usum potissimum studiosae juventutis digestum, ab Andrea Jambressich, Societatis Jesu Sacerdote, Croata Zagoriensi. Zagreb : Typis Academicis Societatis Jesu, per Adalbertum Wilh. Wesseli.

Kos, Koraljka. 1991. Napjevi Pavlinskog zbornika. Pavlinski zbornik 1644. : Transkripcija i komentari. Zagreb : Hrvatska akademija znanosti i umjetnosti - Globus - Nakladni zavod, 1991. Str. 337-360.

Kukuljević Sakcinski, Ivan. 1860. = Bibliografia jugoslavenska knjiga proa. Bibliografia hrvatska. Dio proi. Tiskane knjige. Uredio Ivan Kukuljević Sakcinski. Zagreb : Brzotiskom Dragutina Albrechta.

Kukuljević Sakcinski, Ivan. 1868. II. Jezikoslovci. Arkiv za povjestnicu jugoslavensku. Knjiga IX. Uredio Ivan Kukuljević Sakcinski. Zagreb: U tiskarni Dragutina Albrechta. Str. 184-188.

Marević, Jozo. 2000. Latinsko-hrvatski enciklopedijski rječnik. Velika Gorica - Zagreb : Marka - Matica hrvatska.

Meder, Jagoda. 1989. Orgulje pavlinskih samostana u Hrvatskoj. Kultura pavlina u Hrvatskoj 1244-1786. Slikarstvo, kiparstvo, arhitektura, umjetnički obrt, književnost, glazba, prosvjeta, ljekarstvo, gospodarstvo. Zagreb : Glo- 
Vladimir Horvat, Ivana Klinčić: Belostenec i enigma zagubljene zbirke pjesama...

FILOLOGIJA 67(2016), 49-64

bus - Muzej za umjetnost i obrt. Str. 335-341.

Mikalja, Jakov. 1649. Blago jezika slovinskoga illi slovnik ù komu Komu izgorarajufe rjeci slovinfke Latinski, i Diacki. Thesaurus linguae illyricae sive Dictionarium illyricum. In quo verba Illyrica Italicè, \& Latinè redduntur. Labore p. Jacobi Micalia societ. [...] Lavreti. Apud Paulum, \& Io: Baptistam Seraphinum. 1649.

Pavlinski zbornik. 1644. Pavlinski zbornik 1644: Faksimilni pretisak. Zagreb : Hrvatska akademija znanosti i umjetnosti - Globus, 1991.

Šaban, Ladislav. 1989. Pavlini i glazba. Kultura pavlina u Hrvatskoj 12441786. Slikarstvo, kiparstvo, arhitektura, umjetnički obrt, književnost, glazba, prosvjeta, ljekarstvo, gospodarstvo. Zagreb : Globus - Muzej za umjetnost i obrt. Str. 323-333.

Šojat, Antun. 1991. Kajkavski tekstovi Pavlinskoga zbornika. Pavlinski zbornik 1644. : Transkripcija $i$ komentari. Zagreb : Hrvatska akademija znanosti i umjetnosti - Globus - Nakladni zavod, 1991. Str. 298-336.

Šurmin, Đuro. 1898. Povjest književnosti hrvatske i srpske. Zagreb : Tisak i naklada knjižare Lav. Hartmana (Kugli i Deutsch).

Tuksar, Stanislav. 1983. Nazivlje glazbenog instrumentarija u Gazofilaciju (1740) Ivana Belostenca. Varaždinski zbornik: Zbornik radova sa znanstvenog skupa održanog u Varaždinu od 1. do 3. listopada 1981. godine povodom obilježavanja 800. godišnjice grada. Varaždin : Jugoslavenska akademija znanosti i umjetnosti - Skupština Općine Varaždin, 1983.

Vodnik, Branko. 1913. Povijest hrvatske književnosti : Knjiga I. : Od humanizma do potkraj XVIII. stoljeća : S uvodom V. Jagića o hrvatskoj glagolskoj knjižeunosti. Zagreb : Matica hrvatska.

Vončina, Josip. 1997. Belostenčev hibridni jezik. Suvremena lingvistika, 4344 (1997), 325-339.

Vončina, Josip. 1998. Promicatelj hrvatskoga jezičnog jedinstva. Ivan Belostenec. Gazophylacium. Pretisak. Zagreb: Stari grad. Str. 5-30. [U knjižici koja je samostalni dodatak pretisku.]

Zagorac, Vladimir. 1991. Povijesno-liturgijski aspekt Pavlinskog zbornika. Pavlinski zbornik 1644. : Transkripcija i komentari. Zagreb : Hrvatska akademija znanosti i umjetnosti - Globus - Nakladni zavod, 1991. Str. 285-297.

\section{Arhivsko gradivo}

HR-HDA-652. Pavlinski samostan Novi Vinodolski, sv. 36, spis br. 1/33: Altum Inventarium et Regesta Terrena - Convictus Novi.

HR-MP-127. Catalogus Authorum Seu Scriptorum Ex Religiosis ordinis S. Pauli primi Eremitae, Qui aliqua Doctrina aut pietatis monumenta Scriptis ediderunt. Collectus per P. T. Nic. Ben. eiusdem Ords. 
Vladimir Horvat, Ivana Klinčić: Belostenec i enigma zagubljene zbirke pjesama... FILOLOGIJA 67(2016), 49-64

\title{
Belostenec and the Enigma of the Lost Collection of Poems about St. Paul of Thebes
}

\begin{abstract}
In the mid- $18^{\text {th }}$ century, Paulist chronicler Nikola Benger mentioned in a list of books that Ivan Belostenec had published a collection of poems about St. Paul of Thebes in 1665, a book which entere Croatian literary and linguistic history under the title of Bogomila. No trace of this book has ever been found, however there are witness accounts of its existance in two more recent manuscripts: 1. Altum Inventarium et Regesta Terrena - Convictus Novi (1722); 2. Nikola Benger: Catalogus authorum seu scriptorum (1766). The book mentioned in the inventory of the Novi monastery and the book described in Benger's list have three common characteristics: the titles of both begin with Bogomila, the poem about St. Paul of Thebes in both sources is described as a song with the Kajkavian "slatkopopevka" and Latin "melodia", and both were written in the Croatian language using northwestern Croatian graphy. On the basis of this information, we have concluded that the two books are one and the same. As the Paulists dealt in liturgical singing, the fruit of their work is the manuscript Paulist Anthology ('Pavlinski zbornik'), part of which is also the Paulist Songbook ('Pavlinska pjesmarica'). We expected the lost poem to be included in the Paulist Songbook, however it contains no songs about St. Paul of Thebes. We consider it likely that the Paulists collected songs about St. Paul of Thebes and decided to publish them as an independent book in honour of their patron saint, and that they entrusted the task to the experienced and respected Father Belostenec.

Ključne riječi: Ivan Belostenec, Nikola Benger, Bogomila, pavlini, crkvene pjesme, 17. stoljeće

Key words: Ivan Belostenec, Nikola Benger, Bogomila, Paulists, church songs, 17th century
\end{abstract}

